\author{
Kateryna Havrylenko \\ National Technical University of Ukraine \\ «Igor Sikorsky Kyiv Polytechnic Institute»
}

\title{
DISTANCE LEARNING TECHNOLOGIES IN STUDENT TRAINING
}

Distance learning has always offered to learn much more opportunities than formal educational systems. The paper is devoted to the study of the distance learning development in combination with available computer technologies and modern methods of teaching. The analysis of scientific literature showed the possibilities for bringing innovation and offering new methods and modes of learning. A brief overview is given of the process of the distance education implementation for helping students fulfill their professional aspirations. The role of distance learning in the system of higher education of Ukraine has been outlined, the main advantages and problems of introduction and developing of distance courses into the educational process are determined.

Keywords: computer technologies, distance learning, distance education, distance learning characteristics, knowledge-based educational environment.

Introduction. Development of a new generation of students with creative thinking is a demand of modern society. Therefore, the reformation of the higher education system in Ukraine strives towards the recognition of a student as a central figure in the educational process as well as the increase of his cognitive abilities. This involves an adaptation of the educational process to its ultimate goals in the maximum breakthrough of individual potential and personal self-development of each student. One of the most important directions of modern higher education development is the use of distance learning in the educational process [2].

A distant form of learning for specialists is a strategic goal for the educational system of the 21st century. The relevance of the problem of distance learning lies in the fact that the results of the teaching-learning process, previously concentrated in the employment of educational technologies, today concerned with the importance of information distribution, especially when professional knowledge ages very quickly, it is necessary to keep it up to date.

Distance learning enables the foundation of systems of continuous self-education and overall exchange of information. These systems are able 
to respond the most adequately and flexibly to the social requirements in training of highly qualified professionals. The distance education is gradually developing as the most effective system of training and continuous support of higher education.

Theoretical framework. Recently, the problem of distance learning is gained much attention in the scientific literature. The distance education system has been at the center of discussions of the academic circles, and current trends indicate the further intensification of research in this area. Specifically, theoretical and methodological problems of distance learning in higher education were studied by such scholars as A. Kaplan, M. Haenlein, M. Moore, G. Kearsley, V. Pittman and many others.

Researchers J. Clark, F. Lee, M. Burns quite reasonably believe that the goals, content, and technologies in the current educational practice do not meet modern requirements and cannot provide adequate training for a specialist in technological society [4; 5;9]. Current teaching should be aimed not just at raising the level of general humanistic education, but at the development of a new type of intellectual student with a different way of thinking, adapted to the rapidly changing economic, technological, social realities of modern world; based on an understanding of the leading role of information as a natural phenomenon of the community. An important aspect is the need of an informatics student in self-development.

The aim of the study. The high rates of computerization of the society brought to the worldwide spreading of various aspects in scientific and educational information, which leads to the complexity of collecting, storing and processing large amounts of information. There is a problem of obtaining the educational information and the planning structured and modular courses. Nowadays, computer technologies and global telecommunications networks have begun to change the opportunities for formal training in the classroom as well as for individual self-study and selfdevelopment.

The purpose of the article is to determine the role of distance learning in the system of higher professional education, the main advantages and problems of its development and introduction of distance learning courses in the educational process.

Main aspects of research problem and results. Currently, the development of the education systems through distance learning is constantly changing its structure and context for increasing effectiveness in creating different projects and tasks, as well as training courses and materials. Distance learning techniques are a natural, adequate and effective means of reorganizing and modernizing teaching-learning activities applying computer technologies. Distance learning techniques are the most suitable system for wide practical application in both scientific research and, in particular, the student's educational process as the efficiency of the 


\section{Збірник наукових статей}

large-scale work on the creation of educational and methodical courses based on computer technologies implemented in higher educational institutions and is dependable on the problem of creating appropriate databases. The subjects of educational process do not need to have skills in programming to shape their own network and solve problems, which greatly expands the circle of users [1, 442]. Distance learning techniques do not provide immediate links between the students and tutors, which excludes a number of negative psychological aspects that might hinder wider implementation of computer technologies. Moreover, distance learning techniques are flexible; the same system can provide an opportunity for learning in different directions.

We should not identify distance learning and correspondence education. Their main difference is in systematic and effective interaction ensured by the distance learning. Distance learning as a new form of education and, consequently, distance education (as a result, a process, and a system) should be considered as a new form of education, although it cannot be regarded as a completely autonomous system. Distance learning is organized in accordance with the same goals and content as the full-time training, but the forms of the presented material and the forms of interaction between the subjects of the educational process are significantly different. The didactic principles of distance learning organization are similar to the basic training principles, but their implementation is specific [4].

Distance learning facilitates the promotion of students' the interests and serves the needs of teachers as permits to make the best of numerous educational resources, providing an unlimited educational space for different categories of students. Modern distance learning systems support centralized computerized training management, fast and effective placement and training content provision, a single platform for multi-tasking in planning, implementation and management of all training activities, support modern standards in distance learning techniques, personalize educational content and give possibilities of its repeated application, provide a wide range of means for organizing interaction between all participants of the learning process.

The analysis of modern trends in the educational process demonstrates that the necessity in creating different distance learning systems in a knowledge-based educational environment is determined by the range of factors:

- Intensification of the tendencies in the creation of international educational structures;

- Rapprochement of the specialists' training levels through the exchange of educational resources, as well as accumulating experience in the application of distance learning systems $[6,61]$. 
The main attributives characterizing distance learning should be introduced in the list mentioned below:

- Interactivity of learning, which permits to receive feedback, providing dialogue and support not possible in most traditional training systems;

- Flexibility of distance training in the choice of educational institution, place and time of the study. Students have the opportunity not to attend training sessions, and study at a convenient time and in a convenient place;

- Personalization of distance education through planning a range of independent module courses for a curriculum which meets the students' needs and permits students to implement an individual curriculum as well as to choose the sequence of studying subjects according to an individual plan;

- Effectiveness of distance learning is realized through the effective use of training space and facilities, which leads to lower costs for specialist training;

- Technological approach is stated in the implementation of information technologies for the educational process providing technological learning;

- Informational is characterized by the fact that students receive access to a range of necessary educational materials electronically and directly from the higher educational institution servers and Internet resources.

- Simultaneousness of distance learning is carried out through combining of professional and studying activities as well as simultaneously studying in the Ukrainian and foreign universities;

- Openness and objectivity of the students' knowledge assessment, independence from the teacher's subjective opinion, implementing corresponding programs of evaluation;

- High self-organization, which depends on the student's ability to gain knowledge by means of latest computer technologies [8; 11].

The analysis of the development of distance learning abroad revealed that the most interested in it the countries with large territories and disproportions in the distribution of educational institutions: the USA, Canada, Brazil, and British Commonwealth of Nations. The development of the Bologna education system has made the introduction of distance education much easier.

The territorial isolation of some regions and the inaccessibility of many educational resources for their population impedes obtaining a professional education and this is by no means could be solved through the development of distance learning systems. However, distance learning technologies have some problems, which can be singled out: 


\section{Збірник наукових статей}

- Correlation of distance and traditional courses as well as their the recognition along with traditional full-time education;

- Language problem as distance courses might require financial costs for their translation into another language, including consideration of social, cultural and other characteristics of the regions where distance learning will be conducted;

- Different level of the development of computer technologies in particular data transmission channels as insufficient bandwidth of data transmission channels hinders seriously distance learning possibilities;

- Shortage of competent specialists for supporting, planning and creation of distance learning technologies; courses;

- High cost of development and maintenance of up-to-date distance

- Exploitation of real-time communication in some regions;

- A large number of misconceptions accompanying distance learning, due to a large number of organizations that use invalid distance learning technologies [10].

The prerequisites for the interest to the distance learning in a science-intensive educational environment, in particular, for the students training are social and pedagogical. Social conditions include external and internal prerequisites. External prerequisites depend on in the development of computer technologies in the society and the level of the computer skills of a modern student:

- Computer application in industrial enterprises, educational institutions, scientific institutions, etc.;

- The necessity in creation and application of a single information space for professional information.

Internal prerequisites are related to the inner problems of the education system in a knowledge-based educational environment concerning computer technologies: information;

- An increasing amount of educational, scientific and professional

- Searching for new effective methods and techniques for the learning process optimization;

- Focusing on student-centered learning;

- Specialists training in the rapidly changing technological society.

Thus, the external prerequisites are conditioned by the social demands and computer skills development. The internal prerequisites are required by the system of student training and use of modern computer and communication technologies [11].

Teaching a student in the distance learning system in a knowledgebased educational environment makes the organization and administration 
of the studying process irrelevant since the system itself acts as a medium and as a means of the student's training.

One of the prerequisites is the creation of the conditions for the training intensification. A range of aspects has not been sufficiently developed and described in the pedagogical and psychological literature. The necessity of intensification arises from the demand for the improvement of the learning process effectiveness combined with the constantly increasing amount of information and the required professional knowledge expansion. Intensification of training is aimed at resolving the contradiction between the information amount growth and terms of education shortening. Intensification means the maximum use of the inner reserves of the learning process by consolidating the educational information, rational distribution of the learning time, the cognitive activities activation, students' motivation stimulation, computer technologies application in teaching up-to-date professional skills.

Additional prerequisite for the use of computer and communication technologies is the need for a transition to student-centered learning. The main aim of the learner-centered approach is the orientation toward the individual student's needs as the goal, the student becomes the subject and the main criterion of the effectiveness of the distance learning process in a knowledge-based educational environment. The main components of this approach are the recognition of the uniqueness of each student and his/her individual learning activities. The role of the teacher is not to transfer knowledge and skills, but the organization of such an educational environment that allows the students to develop their potential and the application of the appropriate learning-teaching technologies. The student and the teacher mutual efforts create a joint educational environment aimed at the student's individual self-realization and the development of his/her personal qualities.

Conclusions. The use of distance learning technologies has a significant impact on the educational process, although their application is justified only by an increase in quality of instruction, time and effort spent by teachers and students, as well as financial costs.

The introduction and development of distance learning in Ukraine outlined in this article do not cover the complete range of problems concerned distance education. Each of these problems and their solution requires further deep and comprehensive study on pedagogical and psychological levels and as a result, provide the background for further researches on the development and implementation of distance learning. 


\section{Збірник наукових статей}

\section{References}

1. Kaplan, A., Haenlein, M. (2016). Higher education and the digital revolution: About MOOCs, SPOCs, social media, and the Cookie Monster. Business Horizons, 59 (4), 441-450.

2. Moore, M. G., Kearsley, G. (2005). Distance Education: A Systems View (2nd ed.). Belmont, CA: Wadsworth.

3. Pittman V., Correspondence Study in the American University: A Second Historiographical Perspective, in Michael Grahame Moore, William G. Anderson, eds. Handbook of Distance Education, pp. 21-36.

4. Clark J.J., The Correspondence School - Its Relation to Technical Education and Some of Its Results, Science (1906) 24\#611, pp. 327-8, 332, 333.

5. Lee, F. (2008). Technopedagogies of mass-individualization: Correspondence education in the mid twentieth century. History and Technology. 24 (3): pp. 239-53.

6. Bunker, Ellen L. The History of Distance Education through the Eyes of the International Council for Distance Education, in Michael Grahame Moore, William G. Anderson, eds. Handbook of Distance Education, pp. 49-66.

7. Daniel John S. (1998). Mega-universities and Knowledge Media: Technology Strategies for Higher Education. Routledge. 224 p.

8. Lever-Duffy, Judy; McDonald, Jean B (March 2007). Teaching and Learning with Technology. Ana A. Ciereszko, Al P. Mizell (3rd ed.). Allyn \& Bacon. p. 377.

9. Burns Mary (2011). Distance Education for Teacher Training: Modes, Models, and Methods. Washington, DC: EDC. 328 p.

10. Cuban Larry. (1986). Teachers and Machines: The Classroom Use of Technology Since 1920, pp. 11-18.

11. Oblinger Diana G.. (2000). The Nature and Purpose of Distance Education. Available: http://technologysource.org/article/nature_and_ purpose_of_distance_education/. Last accessed 22.10.2017.

Екатерина Гавриленко. Дистанционное обучение в подготовке студентов.

Дистанционное обучение всегда предлагало гораздо больше возможностей, чем традичионные образовательные системы. Статья посвящена изучению развития дистанщионного обучения в сочетании $c$ доступными компьютерными технологиями $u$ современными методами обучения. Анализ научной литературы показал возможности для внедрения инновачий и использования новых методов и способов обучения. В работе приводятся основные факторы, способствующие внедрению дистанционного образования, названы его основные характеристики, возможные модели 
образования и учебные методы. Приводится краткий обзор проиесса имплементачии дистанщионного образования для помощи студентам по обучению профессиональным навыкам. Определена роль дистанционного обучения в системе выстего профессионального образования Украины, указаны основные преимущества и проблемь внедрения дистанционных курсов в современный учебный процесс и их развития.

Ключевые слова: дистанционное обучение, дистанционное образование, компьютерные технологии, образовательная среда, наукоемкая образовательная среда, профессиональное дистанционное обучение, характеристики дистанциионного обучения.

\section{студентів. \\ Катерина Гавриленко. Дистанційне навчання у підготовці} Дистанційне навчання завжди пропонувало набагато більше можливостей, ніж традиційні освітні системи. Стаття присвячена вивченню розвитку дистанційного навчання у поєднанні з доступними комп'ютерними технологіями та сучасними методами навчання. Аналіз наукової літератури показав можливості для впровадження інновачій $і$ використання нових методів і способів навчання. В роботі наводяться основні фактори, що сприяють впровадженню дистаниійної освіти, названі ї̈ основні характеристики, можсливі моделі освіти і методи навчання. Надано короткий огляд процесу імплементації дистанційної освіти для допомоги студентам у навчанні професійним вмінням навичкам. Визначено роль дистанційного навчання в системі вищої професійної освіти України, вказані основні переваги та проблеми впровадження дистанційних курсів у сучасний навчальний процес та їх розвиток.

Ключові слова: дистанційне навчання, дистанційна освіта, комп'ютерні технології, освітнє середовище, наукомістке освітнс середовище, професійне дистаниійне навчання, характеристики дистаниійного навчання.

Стаття надійшла до редакційної колегії 29.10.2017

\section{Інформація про автора:}

Гавриленко Катерина Миколаївна - кандидат педагогічних наук, старший викладач, Національний технічний університет України «Київський політехнічний інститут ім. І. Сікорського». 